\title{
Ruth Iowa Jones Myers, 1887-1974: Rural Iowa Educator
}

\author{
Evelyn Myers Hickle
}

$\mathbf{R}$ UTH IOWA Jones was born in the late nineteenth century in Epworth, Iowa in an era when the movement for women's suffrage and women's rights was well under way. Led by Elizabeth Cady Stanton, Susan B. Anthony, and others, the movement was helping women gain educational and professional opportunities. While the majority of women remained in "woman's sphere" of the home and family, increasing numbers were using what they termed their moral guardian philosophy - the importance of woman's influence on children as future citizens-by accepting teaching positions, and this is where Ruth Jones found herself following high school graduation.

She was born into an education-oriented family. Her mother, Sadie Platt Jones, graduated from Upper Iowa University in Fayette, Iowa, and taught music at Epworth Seminary. Ruth's father, George Washington Jones, graduated from Cornell College, Mt. Vernon, Iowa, after intermittent terms of country school teaching to earn his way. He became principal of Epworth Seminary where Sadie Platt was teaching and they were later married. ${ }^{1}$

\footnotetext{
${ }^{1}$ The sources for this essay are Ruth Iowa Jones Myers's writings and speeches: her unpublished autobiography, "Reflections," 1968, author's possession; articles published in The School Century, vols. 4-6, 1907-1909; and addresses Mrs. Myers gave to meetings of the Farm Bureau and women's clubs
} 
Ruth described the seminaries: "In that day [1880s], there were seminaries to take the place of the high schools which were almost non-existent. There were tuition fees and similar expenses as colleges have, so only the children of families who could afford it were able to attend."

The family lived at Dubuque, then moved to Oak Park, Illinois, where George $W$. Jones became editor and publisher of educational journals. He acquired The School Century, a journal "devoted to education and better schools," and was its editor from 1905 to 1924 . His daughter was to become one of its contributors. Ruth Jones's early life in Oak Park was in a middle-class family which kept a "hired girl" who worked for two or three dollars a week. Her mother died when Ruth was five and the little girl was sent to live on her grandparents' Iowa farm, land on which they had "staked out a claim" in 1857 in Bremer County.

Under dear Grandma's care were my happiest childhood years; I have such pleasant memories of the many stories she used to tell me of her earlier years ... what pioneer life had been like-she told how they first came to Iowa, coming by train from Ohio to the Mississippi River, then crossing the river on the ice in a bob sled. Ordinarily, they used a ferry, but when the ice was good and thick they used a bob sled, and this was the last load of people they could take across until the ice melted. Grandma sat with my father, then two years old, by her side and she held Aunt Alice. She watched the sled runners cut in the ice and the water ooze into the tracks the sled runners made. It was a most terrifying ride.

After the massacre at Spirit Lake, Iowa, the settlers in Iowa were quite frightened about the possibility of attacks. The news came from some source that the Indians were planning an attack on all the settlement thruout [sic] the area where Grandma was living, so the settlers picked up most of their belongings and gathered at a Garner place near the site of Janesville. They stayed for a time until the scare passed . . . The Indians went

in Bremer County and Butler County in the 1930s, and to the American Country Life Association Convention in Madison, Wisconsin in 1930. These materials are in the author's possession. 
through north of their area ... I read aloud to Grandma while she worked and wrote letters for her at her dictation because she was afflicted with shaking palsy that made writing difficult.

Another account of crossing waters to reach a destination tells of Clif Myers's grandparents, Abraham and Hester Ann Myers, crossing the Cedar River at Janesville, Iowa, in the spring of 1851. (Their grandson was to become Ruth Jones's husband.) Abraham lashed two canoes together and ferried the wagon, family, and small stock across because of high water after the spring rains; the cows and oxen swam the river. The family had moved from Pennsylvania by way of Washington County, Iowa.

Ruth Jones's first educational experience was as a student tutored by a neighbor of her grandmother's. She entered the third grade at age eight upon returning to live with her father and stepmother in Oak Park. The city high school was similar in quality to present-day junior colleges; and although Ruth later expressed a lack in not having earned a college degree, her high school education compared favorably with today's college curricula. Her Latin and advanced mathematics are more commonly found in colleges than high schools. Incidentally, one of her fellow students at Oak Park High School was Ernest Hemingway, and she felt fortunate to have known him.

The adolescent girl was impressed with an "outstanding caliber of ministers" in the Oak Park religious community. She later related that "The Sabbath was observed in those days, and attendance at the various services a regular part of life." She was baptized and received into the Methodist church membership in Oak Park at about age twelve and enjoyed church activities for children and youth. She was particularly impressed with a large church in Chicago: "the essence of reverence," with music from the "best pipe organ in the West at that time."

Cultural opportunities in the city such as the Art Institute, Field Museum, Arboretum at Garfield Park, and Lincoln Park Zoo were valuable assets to any adolescent. Theater entertainment was live, and Ruth was taken to such plays as Shakespeare's Julius Caesar. The Oak Park Library was a favorite place. In addition, her father had access to many children's 
books which he reviewed for his publications. All of these left their mark on the girl and she later wrote, "Of themselves, I can't say they offset the value of fresh air, freedom and living close to Nature that are a country child's life." They did, however, help prepare her for later teaching in country schools and her farm community.

Ruth Jones graduated from high school in 1906 and returned to Iowa to help her grandmother. She had part-time jobs of sewing, working in a general store, and writing for her father's school publication, The School Century. Her published contributions during 1907-09 were in sections called "Stories for Reproduction in Primary Grades" and "The Teacher and the School, Perplexing Problems of the Profession."

Teaching in country schools began at this time for her. Preparation for the position consisted of a two-week county institute in addition to high school graduation. She attended the Butler County Institute taught by professionals from Iowa State Normal School, Cedar Falls, Iowa. Her first teaching position was at Prairie Mound School, west of Shell Rock, Iowa for a salary of twenty-five dollars per month. Her board and room cost two dollars and fifty cents per week and she walked the three-quarters of a mile to the school house. She described her first day in The School Century:

It requires no flight of fancy or imagination to recall to my mind the queer sensations of strangeness and unreality with which I started out that first Monday morning as the "new teacher" of a little country school in one of the northeastern counties of Iowa. My youth and inexperience loomed up as great bugaboos in my thoughts, mocking my courage with every step I took over the dew-sprinkled dusty road in the early autumn morning. The dazzlingly bright September sunshine was cheering as I trudged resolutely on the way from my boarding place to the schoolhouse with tin dinner-pail, books, and all; but the very wind seemed to my excited sensibilities to be whispering mockingly in the tops of the great willows I passed, of things cruelly, painfully true of me and my faults, and of how I should possibly fail in this first attempt in the capacity of school teacher.... 


\section{The Annals of Iowa}

After a walk of some three quarters of a mile, I suddenly found myself at the very door of the schoolhouse, which had been hidden from my sight before by a clump of low-grown willows to the south of it. There it stood on a slight elevation of ground, such a meek looking, silent, little, white frame building, surrounded with the willows, excepting in front, where it looked out westward from its secluded nest over the acres of of farms, with a marshy valley of grassland lying to the north. To the back, beyond the willows, were the fields of waving corn, standing thick and high and helping to make the whole place one of seclusion and loneliness except for the myriads of birds darting gaily here and there, with feathers glinting in the warm sunlight. ...

The interior of the average country schoolhouse in a western state is not apt to give one any very cheering impressions upon first sight. . . . First there was the small, bare vestibule with rows of pegs protruding from paint-marred walls. Inside the schoolroom itself were the rows of dusty seats and desks, brown with long usage and so aged as to be somewhat feeble and tottery on their legs; a teacher's desk, or rather a table of the humblest style, and behind it was a chair minus some halfdozen rounds from the back and legs and resembling greatly in appearance those chairs in which we are accustomed to see the street loafers of a country village comfortably lounging on the shady side of the street on a hot summer's afternoon. A single blackboard ran across the front of the room behind the teacher's desk, but was blackboard only in spots. The other three walls were decorated with an art collection gathered from seed catalogs and fashion magazines, which was wonderful in its variety, quality and quantity. The decently good stove in the middle of the room and a dilapidated old organ completed the furnishings of the room whose lack of a single article of beauty smote so severely on my sense of the ideal and what I had hoped for as to well-nigh completely discourage all my plans.

But I hadn't long to think about it, for the merry shout of children's voices was already near and it put heart into me; for, thought I, may not there be light hearts, joyous spirits even in this hard, uncompromising environment? The children were happy; I must be also. It was for me to live down the influence 
of the environment in which I must work, and make the school something worthwhile to the pupils. . . . In every child, however peculiarly constituted, there is some innate good, if we only know how to patiently seek it out and then cherish and encourage it to a growth that will tend to overcome the evil tendencies. . . . If I had only known this in the beginning . . . I should have found the matter of discipline much simpler than I did.

Ruth Jones's primary concerns for her students' development is reflected in the preceding paragraph. Sometimes this development was halted by factors beyond her control. On one occasion a disturbing disciplinary problem occurred; it was solved only by the parents' withdrawing two big boys from school to start farm work a little earlier than usual. Since the school year was divided into fall, winter, and spring terms, farm children were kept at home as needed and many attended only two terms. It was not unusual for the two-term-per-year larger boys to be difficult, and, like other teachers in similar situations, Ruth learned to deal with them.

A seven-year-old Indian boy attended her school at Winslow located in Black Hawk County, a mile south of Bremer County. Ruth reported that the boy's parents came north from the Tama Indian Reservation. Every winter they came to hunt and trap, and they pitched a tent at the foot of the woodsy hill where the schoolhouse stood, living there throughout the winter. Little Henry was very silent as compared with most children that age, but I am sure he didn't understand our language very well, and I did not feel I made much progress with him.

A little while before Christmas, he broke a collarbone on the playground and did not come back to school, so I ventured down to the wigwam to take him a little gift and treat; and I had my first and only glimpse inside a real teepee or Indian wigwam. I hadn't known how to get attention-no place to knock! So I called to Henry and after awhile several pairs of black eyes peeked out through the tent-flap. It was very smoky and huddled-looking inside. There was a fire in the middle. I wasn't invited in and there were no thank-yous for the treat, but I knew they didn't know how to say the words.

A country school teacher spent a major part of her after- 
school hours at the home where she boarded. Ruth found that it was a plus when the farm couple was kind and friendly and a real bonus if the woman was also a good cook. The farm wife and the lady teacher, while doing dishes or some other task, often discovered similar interests to discuss.

The cultural contrast between city and rural living was of great concern to Ruth Jones. Many farm families found work and physical survival paramount in their lives. She felt that it was a dreary existence for those who seemed devoted to an entire life of work with no time for anything else:

Have you ever visited the homes of any of your pupils in the average country community and noted the absence of books, especially children's books, and periodicals? Were there any books besides the Bible and a few volumes of agricultural reports and a history of the county? Did you see any papers excepting the county weekly and agricultural journals? Was there an organ or piano in the home? Could any member of the household bring music from the instrument. . . . Did the members of the household ever sing?

... Such things as reading and music were considered as only time consumers. ... There are exceptions to this sort of a home, but I am speaking of the average one in the middle west communities where the population is of a heterogeneous nature. .. . The barrenness of the average farm family home life [1909] is appalling. . . . The sad part is that the farmer's children grow up into the same undeveloped, uncultured sort of folk when their school does not implant in them a taste for the things that together with their persevering energy and industry will tend to develop a more complete and perfect life.

As teachers we must put something of joy and beauty and hope into the child-lives with which we come in contact. . . . I know of nothing more valuable to that end than the liberal and judicious use of song and story in the country school. The school library itself, if one exists, cannot be depended upon to supply the story, nor an organ the song. There must be a teacher who loves both with a whole heart, and is possessed of a rich fund of stories to tell and songs to sing, and one who tells the stories and sings the songs. . . . The teacher who can skill- 
fully use her stories, interweaving them generously, yet not extravagantly, with the daily school work is a veritable angel of light.

Ruth Jones had previously written about eighty-five short stories which were published in The School Century. Another section of the journal to which she contributed material was "Studies of Noted Paintings" in a French Art Series. The format was an outlined study of a picture and its artist, with thoughtprovoking discussion questions included. Examples of noted paintings brought into the school room in the early 1900s were Feeding Her Birds, J. F. Millet; Girl Spinning, Millet; At the Water-Trough, Dagnan-Bouveret; Lesson in Boatbuilding, Henry Bacon. The teacher was encouraged to purchase the small prints available ( $1 \not \subset$ each) to place in the hands of each pupil in addition to the large picture for study. Ruth Jones used this technique in her school teaching and later on when she taught rural 4-H girls in "art appreciation" studies. The cultural enrichment she offered her pupils also included music-she played the piano for her students and introduced the works of well-known composers.

Her philosophy of education of children undoubtedly was based on her father's philosophy. As editor, he stated in the first issue of The School Century (1905):

Today as never before the school, the teacher and the system of education exist for the child rather than the child for the school and the system.... The essential active force in any scheme of education is the teacher, and it is for the purpose of cooperating with the teacher and for giving aid in the actual plans and practices of the profession that this periodical is founded and published. ... Of all the centuries of history this, the twentieth, may rightly be designated as the great educational century. It is a century of schools and school teachers . . . the educational movement surpasses all others in those nations which dominate the world . . . .

The country school teacher spent considerable time in traveling in the early 1900 s since transportation was limited to trains or horses and buggies. Ruth noted, however, that the trains accommodated passengers by stopping at depots scattered about the countryside, depots which were often also used as loading 
stations for cattle. She used trains frequently as she traveled from her grandmother's home weekends to her boarding homes near the schools where she taught: Butler Center, Leeper, Poor Farm of Butler County, Spring Lake in Bremer County, Winslow, and Prairie Mound.

I N THE spring of 1911 Ruth Jones married L. Clifton Myers who was a recent graduate of the Iowa State Agricultural College in Ames. They were married at her parents' home in Oak Park and she wore an "Alice-blue" traveling suit, although the traveling was limited to the trip back to Iowa by train after spending a day or two at Chicago's LaSalle hotel and visiting Lincoln Park Zoo. Clif's sisters met them at the depot in Iowa with a "team hitched to the family surrey, the two-seated top buggy of that day ... we were in time for supper with the family on the home farm . . . it was good to be among them!"

After her marriage, Ruth Jones Myers's career changed from country school teacher to full-time farm wife and soon mother of four children. She conscientiously tried to provide her children with a learning environment and to motivate their interests. They had access to many books, a large blackboard, a piano, and time for family singing around the piano. All were given instruction in piano or voice, or both. In addition, the girls learned traditional skills of cooking and sewing; the son learned how to farm. Ruth and Clif Myers took advantage of new and improved methods of home-making and farming which became available in the community through 4- $\mathrm{H}$ and Farm Bureau programs, and served in leadership roles, resulting in advantages for the children as well. These programs were provided by the federal government to further education in rural areas for farmers, farm women, and youth, to broaden their knowledge and increase their competency in homemaking and agricultural skills.

The Farm Bureau, as an extension service from Iowa State College, was formed in Bremer County about 1917. The rural clubs were formed in the early 1920 s, evolving from boys' and girls' clubs originally begun in central and southern United States to give farm youth experiences in "learning by doing." 
Paid personnel such as county $4-\mathrm{H}$ club agents or agricultural and home demonstration agents served as guides for the organizations.

Ruth Myers was asked to volunteer her help as a 4- $\mathrm{H}$ club leader in 1926 and since the goals of the program appealed to the former teacher and current homemaker, she accepted and served eight years as a club leader. The clubs were one of the first nationally organized groups to provide instruction in the skills of homemaking and farming outside the classroom. Appreciation for art, music, and good health were integral phases of the program. The $4-\mathrm{H}$ clubs provided the positive side effect of children working closely with their parents in cooperative projects. The learning process extended to meetings and county and state fairs where excitement ran high in exhibiting completed projects and demonstrating methods and skills.

Ruth Myers was able to use her communication skills when asked to make speeches to encourage youth and adults to participate in 4-H and Farm Bureau. She also taught homemaking skills to women in rural groups after she had received training from the Iowa State College Extension Service. Whether in the social setting of a living room with farm women, or in an auditorium, she was able to spark creativeness, often dormant, in her audience by emphasizing the application of spiritual and cultural values to the work at hand. To one group of club leaders and parents, she described her vision of a successful club:

They [4-H girls] have acquired a fine foundation for some of the most necessary kinds of work a wife and mother is called upon to perform, and have developed a wide-awake interest in them that will make them always alert for new methods and ideas and discoveries, as well as conscious of the importance of their job in carrying on work so vital to the family and the home. ... Youth loves music . . . and we know it is no more difficult to cultivate a healthy appetite for good music than it is to cultivate a healthy appetite for nourishing foods instead of all pickles and spices and sweets. ... We feel that there are wonderful possibilities in this work of music appreciation. . . .

With the whole nation putting such a premium on health and awarding it such honor (via contests), girls are more and more going to value good health. ... The individual girl and her children... will reap the benefit of this .... 


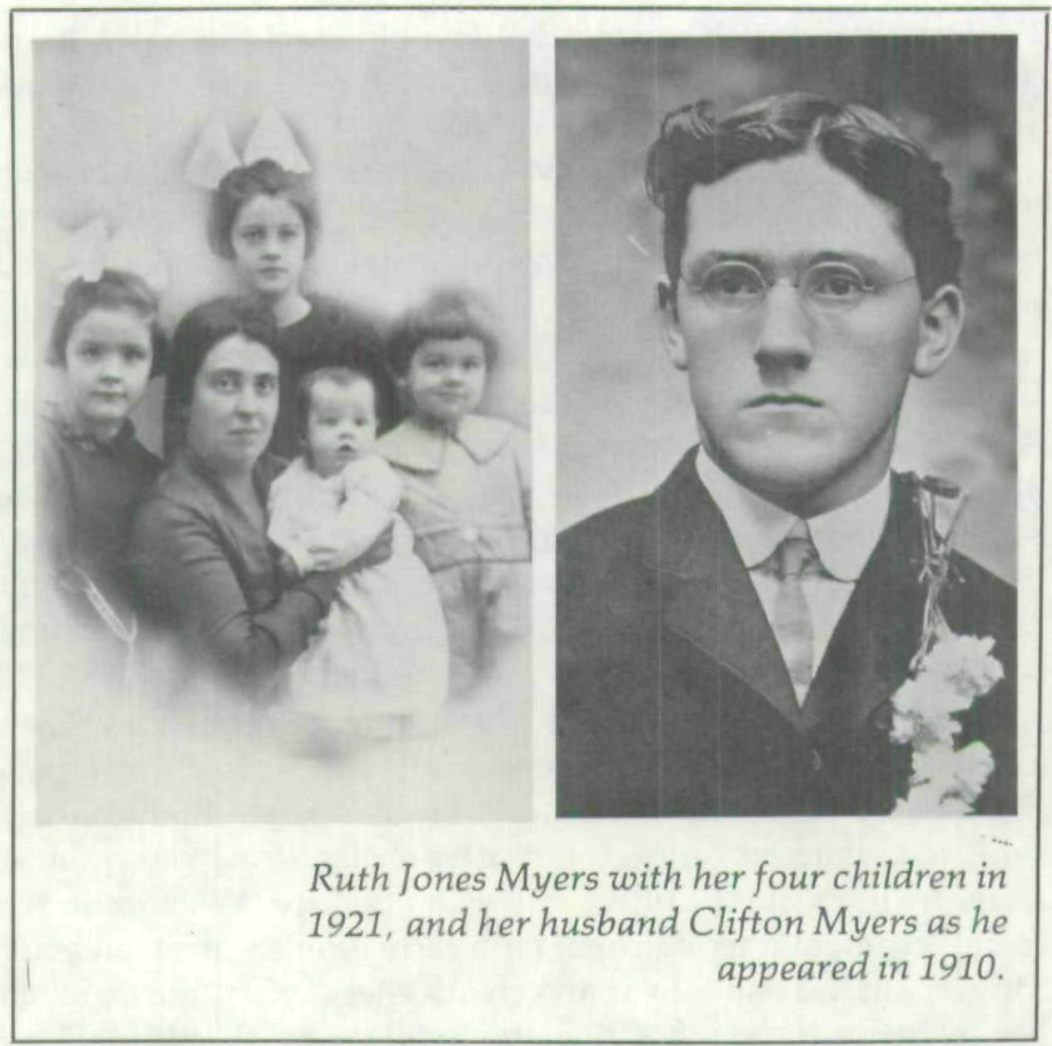

Conducting business meetings is an important feature in 4- $\mathrm{H}$ work and we endeavor to have the girls understand good parlimentary practice. . . . It is worthy of emphasis because the new rural era to which we are looking forward must be one in which there is organization, and organization calls for leaders who know how to lead business meetings and people who know something of the rules governing good business meetings, as well as people who will take an active interest in the conduct of a business meeting. . . .

[4-H work] is also a splendid way of solving many of the perplexing problems of youth by putting into their lives such a variety of interesting and worthwhile work, experience, and pleasure that there isn't much time or opportunity left for them to fill with the undesirable interests and pleasures that are a questionable element in the lives of so many of our boys and girls.... 
There is a very real and abiding satisfaction to every leader in watching the development of her group of girls .... in building the future in their lives and the life of the rural community which is going to be worth so much more in the great scheme of things in ten, twenty, fifty, one-hundred years from now . . . . Lend every encouragement you can to $4-\mathrm{H}$ boys and girls. Interest yourselves in their accomplishments; don't be afraid to give them every bit of honest praise you can for their efforts.....

The urgency to improve rural life continued through the economic depression of the 1930s, and perhaps intensified optimism and hope for the survival of farming and farm families. In an address given at a Farm Bureau banquet, Ruth Myers projected her faith and determination in spite of the country's worsening financial crisis:

... They tell us even if we have occasional spells of despondency we must not despair, for even the sun has a sinking spell every night and then it rises again all right the next morning. If some one here were only wizard enough to be able to turn back for us the pages of time only 100 years and we could find ourselves in this same spot in the surroundings of 1831 instead of 1931, what a startling revelation it would be to find buildings, streets, lights, and all the marks of civilization completely vanished, and all about us only the hushed, wild beauty of untouched Nature on the banks of the Cedar River.

We are so busy in this day, carrying on the program of our modern, complicated life, that it is seldom we give thought to the marvelous growth and progress that have come in this short period of time to this part of the country in which we live.

Ruth Myers spoke with conviction and encouragement to others when her own family was faced with a precarious financial situation. During this time her speeches offered spiritual encouragement.

Now it is our responsibility to maintain a type of rural life that is worthy of our inheritance. . . . We in the country live so very close to our Creator's handwork. The mysteries of Life and growth are the very stuff we work with. The air we breathe is Heaven's own, clean and pure. We work in quiet fields and gardens where we have a chance to think about Life's problems 


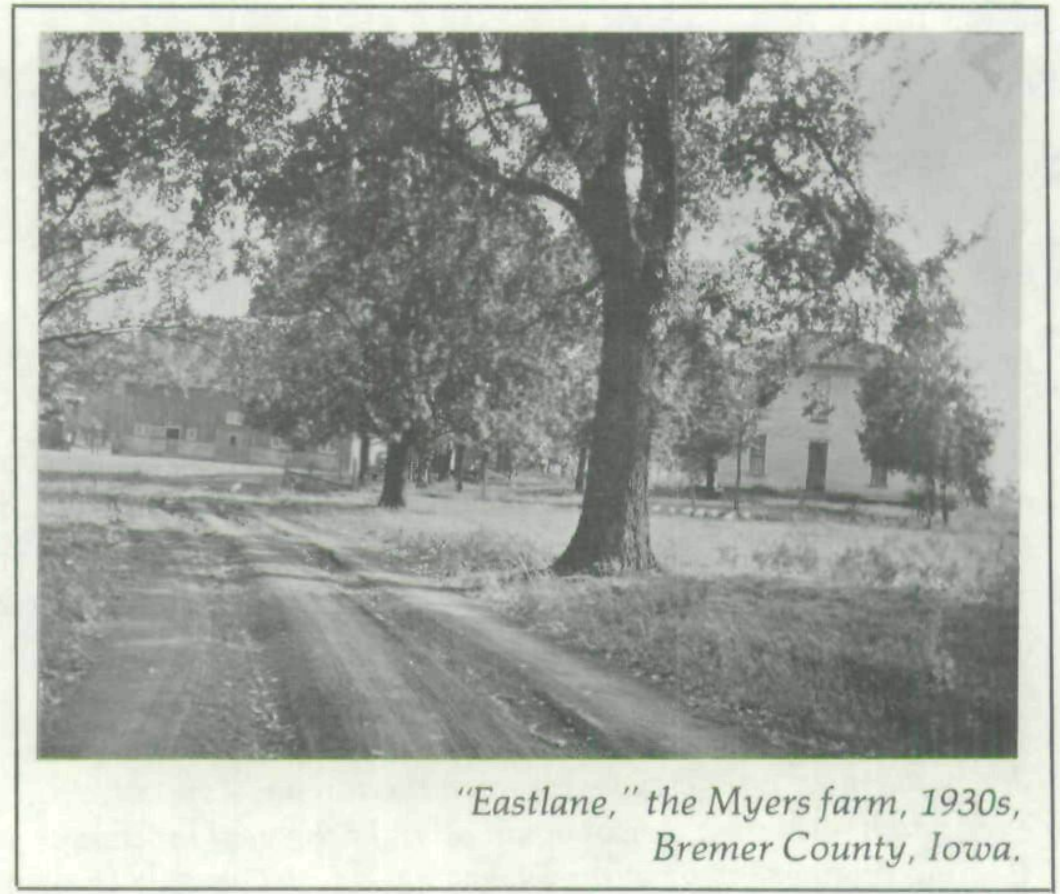

and our Maker. No wonder great men have come in the past from the rural people.

To a Farm Bureau group, Ruth Myers's praise for its progress was qualified by her recognition of human failings:

Human nature is odd: If it's free tickets to a show or free ice cream or some other thing of like fleeting nature, we see people crowding and pushing unbelievably to get the benefits of something for nothing. How is it when something of permanence and value like knowledge or education is being offered free, something which once we have it no man can take from us, we must admit the crowding and pushing is not noticeable. But broad-minded rural parents ought to be anxious that their girls and boys have the advantage of this free special education that is going to fit them in such a practical way for the everyday duties of life.

The annual state $4-\mathrm{H}$ convention held at Ames each spring attracted respresentatives from local clubs. The three-day gathering was alive with choruses, radio broadcasts, leaders' and girls' conferences, and meetings to evaluate and plan yearly 
work. Topics for local club study were scheduled so that two years each were devoted to nutrition, canning, bread baking, clothing and sewing, and home furnishing. The early June date of the state convention, falling soon after schools closed for the summer, and the college campus setting, made it an exhilirating experience for teenage girls. An extra bonus was the bus tour of the capital city of Des Moines, including an elegant tea at the E. $T$. Meredith mansion with its spacious lawn and gardens. In preparation for speaking at one of the state convention banquets, Ruth Myers remembers: sitting up in bed at the rooming house in the early morning hours, with $4-\mathrm{H}$ girls asleep all around me, to work out some notes, feeling skeptical as to whether I could really do it creditably. . . . People were kind in their compliments afterwards and I was asked to give the speech on the radio the next day . . . the family at home were listening and heard it!

In 1930 she was invited to appear at the national Country Life Association Convention at Madison, Wisconsin. She continued to carry the message of intellectual and spiritual development for everyone:

We Americans as a people are so very prone to value practical things a bit too highly, and by so doing unconsciously we can develop a condition of spiritual malnutrition. We need, definitely, to give greater place and value in our homes and our lives to those influences which will beautify and enrich and inspire the spiritual and intellectual side of our existence. It's good books and beautiful pictures and fine music and love and playing together as well as working together that make home and happiness and lives that count. Like folks, it's only by living with fine pictures that we learn to know them and love them and gain inspiration from them .... .

In American country life, the accent has by force of circumstances been largely placed on doing. Until recently, thinking has been a neglected activity, and agriculture today is passing through bitter experiences that are the result . . . . We must be both thinkers and doers.....

Following a Child Life Conference in Washington, D.C. in 1930, a Division of Adult and Parent Education was created. Ruth Myers found herself promoting its aims which were so 
closely related to the whole realm of family life, encompassing aspects of health, education, recreation, and spiritual and emotional growth. She felt that the child must have his or her fair chance in life, must have parents who have the vision of that bigness of the job of parenthood who can realize their own deficiencies and who are eager for self development that they may better understand their children . . . .

Froebel, the pioneer in child education, said, "The child's first school is the family. "How the family will, and most of all the parents, conduct that school is a strong indication of that child's future life. ${ }^{2}$

Many of us labor under the delusion that after our early twenties, study becomes extremely difficult and the acquisition of knowledge increasingly impossible, but it really is all a delusion. . . I.Q. tests show the average adult intelligence of today is on a level with the ten, twelve, and fourteen year-old intelligence of the younger generation, so the need for further education exists, and as never before the times demand a continuance of learning from youth into adulthood.

Ruth Myers found the public library a wonderful resource for bringing books into her farm home. Of even greater service was the Iowa State Traveling Library system through which books were loaned by mail, and the people receiving the books had only to pay the postage. She would send for books regularly, "usually a dozen or so at a time," for the whole family.

By 1939, with her children grown and no longer at home, Ruth Myers accepted a part-time position with the Agricultural Adjustment Administration, a federal program formed in 1935 to provide advice and assistance to farmers and their wives, and to regulate farm production. She met with groups of farm women in the county to give information about the values of the "Triple- $A$ " program, and she wrote articles about the AAA for the newspapers. After a year of this work, she felt the benefits of the program were too intangible for her to "in good con-

${ }^{2}$ Friedrich Froebel, 1782-1852, was a German educator who founded the kindergarten system, believing that education should begin at birth and teacher or parent should guide the physical, mental, and spiritual functions of the child as these impulses develop. 
science" continue to receive a paycheck for her efforts. She resigned and turned to raising strawberries to sell, as well as chickens and eggs.

Ruth Myers's interest in the development of human potential included women, even though the term "women's rights" was not often heard in rural areas in the post World War I era. Women's right to vote had been won in 1920 with the ratification of the Nineteenth Amendment; however, attempts made nationally to maintain pre-suffrage momentum of a women's rights movement met with little success as the severe effects of the depression made economic survival the most crucial issue. Scarcity of jobs usually meant one wage earner to a family, thus a woman's development and contribution was centered in her ingenuity and thrift in homemaking.

By the time of the economic recovery of World War II and the 1950s, many middle class families moved to new suburban homes, and women continued to volunteer their services in their communities. Young mothers, the $4-\mathrm{H}$ girls of the twenties and thirties, were putting into use the skills and knowledge they had gained, and as Ruth Myers had envisioned, they improved the quality of homemaking and the cultural life of their communities.

National events of the 1960s and 1970s were closely followed by Ruth and Clifton Myers. The values they upheld and shared with others through the years brought them many rewards. Ruth Iowa Jones had fulfilled her desire to help develop and build the future of the lives of children and adults in the rural community "worth so much more in the scheme of things in ten, twenty, fifty, one hundred years from now." As far as circumstances permitted, she had developed her own potential by becoming an effective educator in rural lowa. 
Copyright of Annals of Iowa is the property of State of Iowa, by \& through the State Historical Society of Iowa and its content may not be copied or emailed to multiple sites or posted to a listserv without the copyright holder's express written permission. However, users may print, download, or email articles for individual use. 